\title{
PENGARUH SUBSTITUSI ALPUKAT (Persea Americana Mill) DAN TEPUNG IKAN LELE (Clarias gariepinus Burchell) TERHADAP MUTU ORGANOLEPTIK DAN KADAR PROTEIN PADA BISKUIT MPASI
}

\author{
Sepni Asmira ${ }^{(1)}$, Maria Nova ${ }^{(1)}$, Dzulfa Hanum ${ }^{(2)}$ \\ ${ }^{(1)}$ STIKES Perintis Padang \\ ${ }^{(2)}$ Prodi S1 Gizi Stikes Perintis Padang
}

hanumdzulfa11@gmail.com

\begin{abstract}
Abstrak
Makanan Pendamping ASI (MP ASI) merupakan makanan yang mengandung gizi yang diberikan pada bayi atau anak yang berumur 6 - 24 bulan. Untuk mememenuhi kebutuhan gizi pada MP ASI dapat dilakukan melalui diversifikasi dan substitusi pangan. Alpukat dan ikan lele merupakan bahan pangan potensial pada pembuatan biskuit MP ASI kaya akan protein. Tujuan penelitian ini adalah untuk mengetahui pengaruh substitusi alpukat dan tepung ikan lele terhadap kadar protein dan mutu organoleptik pada biskuit MP ASI. Penelitian eksperimental ini menggunakan desain rancangan acak lengkap (RAL) yang terdiri dari tiga perlakuan dan dua kali ulangan. Pengamatan yang dilakukan adalah uji subjektif yang dilakukan terhadap cita rasa (uji organoleptik) dengan 25 panelis agak terlatih dan analisis protein menggunakan metode Kjedahl berdasarkan SNI 01-2891-1992. Data dianalisis statistik dengan menggunakana SPSS 16. Hasil uji organoleptik didapatkan perlakuan yang paling disukai adalah perlakuan B (10 g alpukat: $20 \mathrm{~g}$ tepung ikan lele) dengan indikator penilaian berdasarkan kesukaan terhadap warna, tekstur, aroma serta rasa. Hasil kadar protein terbaik adalah pada perlakuan A (5 g alpukat: $25 \mathrm{~g}$ tepung ikan lele) yaitu sebesar $12,37 \%$, seluruh biskuit dengan ketiga perlakuan telah memenuhi kriteria biskuit MPASI berdasarkan Menkes 2007.
\end{abstract}

Kata Kunci : biskuit, tepung ikan lele, alpukat, MP-ASI

\section{PENDAHULUAN}

Kebutuhan bayi semakin meningkat selaras dengan bertambahnya usia, berat badan dan panjang badan bayi, oleh karena itu ibu harus memberikan makanan pendamping ASI (Air Susu Ibu) guna memenuhi kebutuhan gizi bayi. Makanan pendamping ASI (MP-ASI) dalam bentuk biskuit memiliki beberapa kelebihan yaitu mudah untuk disiapkan dan disimpan dalam waktu lama. MPASI yang baik adalah kaya energi, protein, mikronutrien, mudah dimakan anak, disukai anak, berasal dari bahan makanan lokal dan terjangkau, serta mudah disiapkan.

MP-ASI harus mengandung zat gizi yang dibutuhkan dan sesuai kebutuhan bayi. Zat gizi yang penting untuk bayi salah satunya yaitu protein. Protein merupakan bagian penting selama masa pertumbuhan dan masa perkembangan tubuh manusia, misalnya untuk tulang, otot dan organ tubuh lainnya (Mardhatillah, 2008). 
Berdasarkan Peraturan Menteri Kesehatan Republik Indonesia No 75 Tahun 2013 menyatakan bahwa angka kecukupan gizi protein pada bayi adalah $18 \mathrm{~g} /$ hari. Penduduk Indonesia yang mengkonsumsi protein di bawah kebutuhan minimal adalah $37 \%$. Berdasarkan kelompok umur dijumpai $24,4 \%$ balita mengonsumsi makanan dibawah kebutuhan minimal. Usaha yang dapat dilakukan untuk memenuhi kebutuhan protein adalah dengan memanfaatkan bahan alam yaitu ikan lele yang memiliki kandungan protein tinggi.

Lele merupakan salah satu komoditas unggulan air tawar yang penting dalam peningkatan gizi masyarakat. Komoditas ini mudah dibudidayakan dan harganya terjangkau. Produksi lele ukuran konsumsi secara nasional mengalami kenaikan. Produksi ini terus meningkat selaras dengan tingginya minat dan konsumsi pangan terhadap ikan lele (BPS, 2016). Ikan lele memiliki kandungan gizi yang sangat bermanfaat untuk tubuh manusia karena dalam $100 \mathrm{~g}$ ikan lele terdapat energi 90 kkal, protein $17,75 \mathrm{~g}$, kalium $326 \mathrm{mg}$, dan kalsium $15 \mathrm{mg}$. Setiap zat nutrisi memiliki manfaat terbaik untuk tubuh jika dikonsumsi sesuai dengan kebutuhan. Tingginya kadar protein dalam ikan lele sangat baik untuk meregenerasi sel-sel tubuh, protein juga diperlukan untuk mensintesis DNA dan RNA serta melakukan transport aktif dalam sel. Bahan pangan lainnya yang mengandung protein ialah alpukat.

Alpukat (Persea americana Mill) merupakan tanaman lokal yang disukai oleh banyak orang. Alpukat memiliki manfaat yang sangat bagus untuk tubuh, karena dalam $100 \mathrm{~g}$ buah alpukat mengandung beberapa zat gizi diantaranya energi 85 kalori, protein 0,9 $\mathrm{g}$, lemak 6,5 g, karbohidrat 7,7 mg, kalium $485 \mathrm{mg}$, kalsium $10 \mathrm{mg}$, fosfor $20 \mathrm{mg}$, besi 1 S.I., vitamin A $180 \mathrm{mg}$, vitamin B1 0,5 mg, vitamin C $13 \mathrm{mg}$. (Daftar Komposisi Bahan Makanan, 2013). Alpukat mengandung lemak jenuh sebesar 2,13 g/100 g sedangkan asam lemak tidak jenuh tunggal Imonounsatures fatty acid (MUFA) mencapai 9,8 g/100 g. Alpukat juga mengandung asam lemak tidak jenuh ganda /polyunsatured fatty acid (PUFA) dengan kadar 1,82 g/100 g daging buah alpukat. Tingginya kadar lemak dalam alpukat bermanfaat dalam menurunkan kadar kolesterol, mencegah kanker, penyakit jantung, dan gangguan hati. Konsumsi asam lemak dalam bentuk MUFA dapat memperbaiki kadar kolesterol dan memproteksi kerusakan arteria tau pembuluh darah (Wardani, 2014). Alpukat juga mengandung protein yang tinggi yang dapat membantu meningkatan kadar protein biskuit MP ASI pada bayi.

Mengingat potensi gizi dan ketersediaan buah alpukat ikan lele di Indonesia yang berlimpah, maka upaya diversifikasi buah alpukat dan ikan lele menjadi pangan fungsional perlu dilakukan antara lain dengan mengolah tepung ikan lele dan alpukat menjadi biskuit. Biskuit bayi umumnya dibuat dari bahan dasar tepung terigu atau tepung lain seperti serealia, kacangkacangan, biji-bijian yang mengandung minyak, dan bahan makanan lain yang sesuai.

Substitusi alpukat dan tepung ikan lele dalam pembuatan biskuit MP-ASI diharapkan dapat menjadi alternatif lain dalam memperoleh asupan protein serta dapat meningkatkan daya terima masyarakat terhadap biskuit alpukat dan tepung ikan lele. Serta menjadi solusi dalam pemanfaatan hasil produksi buah alpukat dan ikan lele. Tujuan umum penelitian ini adalah untuk mengetahui 
pengaruh substitusi alpukat (Persea americana Mill) dan tepung ikan lele terhadap mutu organoleptik dan kadar protein pada biskuit MPASI.

\section{METODOLOGI}

Penelitian ini merupakan penelitian eksperimental dengan menggunakan rancangan acak lengkap (RAL). Perlakuan jumlah alpukat dan tepung ikan lele dalam masing-masing perlakuan berbeda.

Alat-alat yang digunakan dalam pembuatan biskuit adalah oven, blender, mixer, timbangan, piring, baskom, spatula, ayakan tepung, kompor, pisau, penggaris, cetakan, kertas label, alat pengering (blower) dan alat tulis. Alatalat yang digunakan dalam analisis kimia adalah pipet volume $(1 \mathrm{ml}$ dan $10 \mathrm{ml})$, beker glass $(100 \mathrm{ml})$, labu ukur $(50 \mathrm{ml}$ dan $100 \mathrm{ml}$ ) neraca analitik, lampu UV, labu destilasi, labu kjedahl, bulb, corong, spatula, cawan aluminium, cawan porselin, tanur, pengaduk magnetic, statif, klem, kertas saring, botol sampel, erlenmeyer, tanur, $\mathrm{pH}$ meter dan texture analiyzer.

Bahan-bahan yang digunakan dalam pembuatan biskuit adalah alpukat mentega, ikan lele dumbo, tepung terigu, garam, telur, susu bubuk, tepung gula, baking powder, mentega putih, vanili, dan air putih. Bahan-bahan yang digunakan untuk analisis kimia adalah aquadest, $\mathrm{SeO}_{2}, \mathrm{~K}_{2} \mathrm{SO}_{4}, \mathrm{CuSO}_{4} 5 \mathrm{H}_{2} \mathrm{O}$, bromcresol green, metil merah, alkohol, $\mathrm{H}_{2} \mathrm{BO}_{3}, \mathrm{NaOH}$ dan $\mathrm{HCl}$.

Alpukat yang digunakan merupakan alpukat mentega dengan kualitas baik dan dalam kondisi matang. Untuk mendapatkan hasil yang baik dalam proses pembuatan biskuit, maka bagian yang diambil adalah daging alpukat yang berwarna kuning.
Pembuatan tepung ikan lele mengacu pada Amirullah (2008) yang dimodifikasi. Ikan utuh disiangi dengan membuang kepala, dan isi perut. Setelah itu ikan yang telah disiangi kemudian dicuci dengan tujuan untuk menghilangkan kotoran yang masih menempel. Kemudian ikan dikukus selama 10 menit (setelah air mendidih) dan dipisahkan daging dari kulit yang masih menempel (bagian yang di buang: kulit, duri, dan sisik). Setelah itu daging dipres menggunakan alat pengepres selama 10-15 menit dengan tujuan untuk menghilangkan air dan lemak yang terdapat pada daging. Setelah dilakukan pengepresan, daging ikan di grinder untuk mengecilkan ukuran kemudian dikeringkan menggunakan oven pada suhu $60^{\circ} \mathrm{C}$ selama kurang lebih 15 jam. Daging ikan yang telah kering dihaluskan menggunakan blender, kemudian disaring dengan menggunakan saringan sehingga dihasilkan tepung ikan yang halus.

Proses pembuatan biskuit mengacu pada Umar (2013) adalah telur, tepung gula, margarin dikocok sampai mengembang selama 15 menit, kemudian pencampuran sampai rata, lalu tepung terigu, vanili, baking powder, susu bubuk, dimasukkan dalam adonan setelah itu dicetak dan dipanggang dalam oven $155^{\circ} \mathrm{C}$ selama 15 menit kemudian menjadi biskuit.

Uji organoleptik yang dilakukan terhadap biksuit yang disubstitusi alpukat dan tepung ikan lele yaitu uji hedonik yang meliputi warna, uji bau/aroma, tekstrur dan rasa. Skala hedonik yang digunakan berkisar antara 1-4 dimana : (1) Tidak Suka Sama Sekali; (2) Tidak Suka; (3) Suka; (4) Sangat Suka. Pengujian ini dilakukan oleh panelis agak terlatih sebanyak 25 orang. 
Kadar protein ditentukan dengan metode Kjedahl berdasarkan SNI 012891-1992 dengan prinsip merubah senyawa nitrogen menjadi ammonium sulfat dengan $\mathrm{H}_{2} \mathrm{SO}_{4}$ pekat. Amonium sulfat yang terbentuk diuraikan dan larutan dijadikan basa dengan $\mathrm{NaOH}$. Amonia yang diuapkan akan diikat dengan asam borat. Nitrogen yang terkandung dalam larutan ditentukan jumlahnya dengan titrasi menggunakan baku asam.

\section{HASIL DAN PEMBAHASAN}

\section{Uji Organoleptik}

Pengaruh substitusi alpukat dan tepung ikan lele terhadap sifat organolpetik dapat dilihat pada gambar 1. Pada gambar 1 dapat dilihat penilaian uji organoleptik biskuit dengan substitusi alpukat dan tepung ikan lele memiliki hasil rata-rata perlakuan terbaik terdapat pada perlakuan B (10 g alpukat : $20 \mathrm{~g}$ tepung ikan lele). Berdasarkan hasil test normalitas data warna, aroma, tekstur dan rasa, didapatkan nilai signifikasi sebesar $(0,00)<(0,05)$ yang bermakna data tidak tersebar normal dan tidak dapat di uji dengan menggunakan Anova. Selanjutnya data di uji menggunakan Kruskal Wallis non parametrik dengan taraf nyata $5 \%$.
Tekstur biskuit didapatkan nilai signifikasi sebesar $(0,017)<(0,05)$ maka dapat disimpulkan bahwa ada perbedaan nyata antar perlakuan.

Berdasarkan dari ketiga perlakuan biskuit dengan substitusi alpukat dan tepung ikan lele, warna yang paling disukai panelis adalah perlakuan C (15 g alpukat : $15 \mathrm{~g}$ tepung ikan lele) dengan warna biskuit coklat. Sedangkan semakin tinggi substitusi alpukat, perubahan warna biskuit menjadi coklat kekuningan.

Biskuit dengan perpaduan komposisi alpukat dan tepung ikan lele yang sesuai menghasilkan tekstur yang lembut. Semakin besar kandungan alpukat maka tekstur biskuit semakin rapuh.

Substitusi alpukat dan tepung ikan lele, aroma yang paling disukai panelis adalah perlakuan B (10 g alpukat : $20 \mathrm{~g}$ tepung ikan lele), komposisi alpukat lebih sedikit dibandingkan tepung ikan lele, aroma nya harum khas alpukat dan tidak amis. Alpukat mampu menutupi bau amis ikan lele.

Rasa biskuit dengan substitusi alpukat dan tepung ikan lele terdapat rasa manis, gurih dan renyah. Panelis kurang suka terhadap biskuit $\mathrm{C}$ dikarenakan tingginya kadar alpukat menyebabkan adanya after taste pahit.

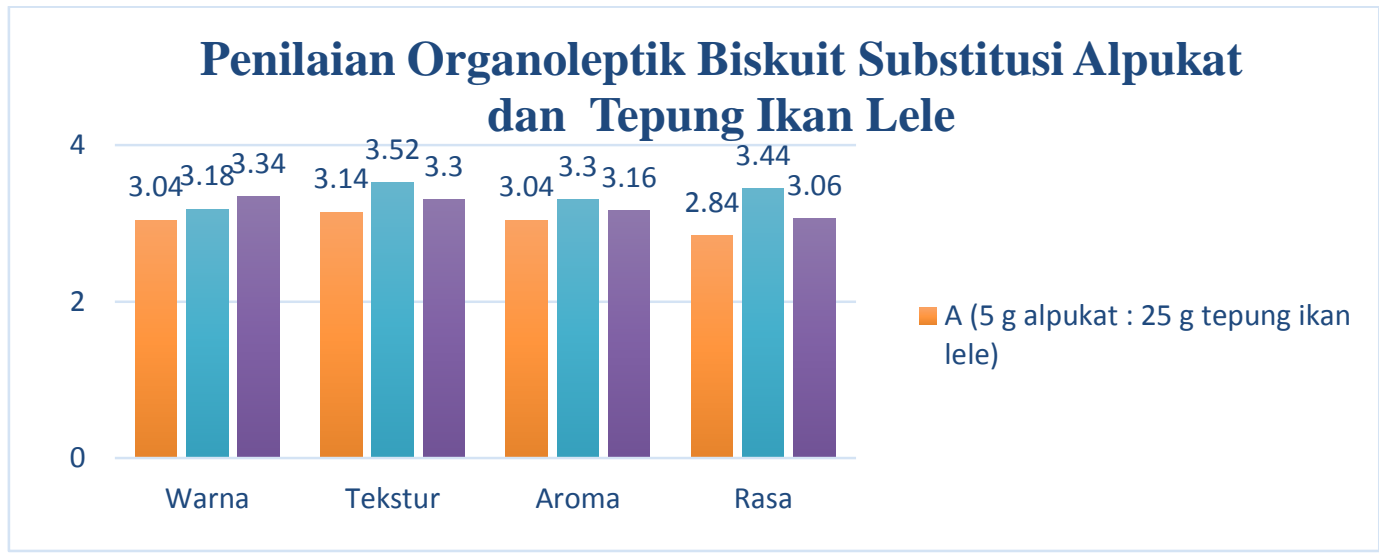

Gambar 1. Penilaian Organoleptik 


\section{Uji Kadar Protein}

Protein juga mempunyai peranan yang sangat penting di dalam tubuh. Fungsi utamanya sebagai zat pembangun atau pembentuk struktur sel, misalnya untuk pembentukan otot, rambut, kulit membrane sel, jantung, hati, ginjal dan beberapa organ penting lainnya. Kemudian terdapat pula protein yang mempunyai fungsi khusus yaitu protein yang aktif. Beberapa diantaranya adalah enzim yang bekerja sebagai biokatalisator, hemoglobin sebagai pengangkut oksigen, hormon sebagai pengatur metabolism tubuh dan antibody untuk mempertahankan tubuh dari serangan penyakit (Sirajuddin dkk, 2010).

Protein digunakan untuk pertumbuhan dan pemeliharaan sel tubuh. Pada bayi dan anak-anak, pertumbuhan berlangsung secara bertahap dan yang paling penting terlihat jelas adalah pertumbuhan ukuran badan (berat dan tinggi badan). Pemenuhan kebutuhan protein bagi bayi dan anakanak sebaiknya disediakan protein yang bermutu tinggi (Husnaini, 2004).

Berdasarkan hasil laboratorium dapat dilihat hasil kandungan zat gizi dalam biskuit dengan substitusi alpukat dan tepung ikan lele memberikan sumbangan protein masing-masing sebesar $12,37 \%$ pada perlakuan A (5 g alpukat : $25 \mathrm{~g}$ tepung ikan lele), 8,82\% pada perlakuan B (10 g alpukat : $20 \mathrm{~g}$ tepung ikan lele), dan 7,95\% pada perlakuan $\mathrm{C}$ (15 g alpukat : $15 \mathrm{~g}$ tepung ikan lele). Kadar protein terbaik biskuit terdapat pada perlakuan B. Perlakuan B terbaik karena pada biskuit ini paling disukai panelis. Untuk Angka Kecukupan Gizi (AKG) protein pada bayi dan anak-anak dapat dilihat pada tabel 1.

Tabel 1. Angka Kecukupan Gizi (AKG) Protein Bayi dan Anak-anak

\begin{tabular}{|l|l|l|l|l|}
\hline Kelompok Umur & Umur & BB $(\mathrm{kg})$ & TB $(\mathrm{cm})$ & Protein $(\mathrm{g})$ \\
\hline Bayi & $7-11$ bulan & 9 & 71 & 18 \\
\hline Anak & $1-3$ tahun & 13 & 91 & 26 \\
\hline
\end{tabular}

Sumber: AKG 2013

Berdasarkan perlakuan biskuit dengan substitusi alpukat dan tepung ikan lele dengan kadar protein terbaik pada perlakuan B sebanyak $8,82 \%(8,82$ g dalam 100 gram). Satu bulatan/keping biskuit dengan substitusi alpukat dan tepung ikan lele memiliki berat $10 \mathrm{~g}$ diperkirakan dalam bulatan satu biskuit memiliki kandungan protein sebanyak 0,882 g $(8,82: 10=0,882$ dan 100 $: 10=10$, jadi $0,882 \mathrm{~g}$ protein dalam $10 \mathrm{~g}$ biskuit, jadi biskuit yg 10 gram tersebut terkandung $0,882 \mathrm{~g}$ protein). Untuk memenuhi kebutuhan protein pada bayi dan anak-anak maka harus mengkonsumsi biskuit sekitar 20 sampai

\section{KESIMPULAN DAN SARAN}

\section{Kesimpulan}

Substitusi alpukat dan tepung ikan lele memberikan pengaruh terhadap warna, tekstur, aroma, dan rasa biskuit MP ASI. Formulasi terbaik biskuit dengan substitusi alpukat dan tepung ikan lele terdapat pada perlakuan B (10 g alpukat : $20 \mathrm{~g}$ tepung ikan lele). Perlakuan B terbaik karena biskuit ini paling disukai panelis dengan warna coklat kekuningan, tekstur lembut, aroma khas alpukat dan rasa manis dan gurih.

29 keping biskuit. 
Substitusi alpukat dan tepung ikan lelel juga berpengaruh terhadap kadar protein biskuit MP ASI yang dihasilkan. Lebih banyak substitusi tepung ikan lele pada biskuit maka kadar protein akan semakin meningkat. Kadar protein tertinggi biskuit terdapat pada perlakuan A (5 g alpukat : $25 \mathrm{~g}$ tepung ikan lele) yaitu sebesar 12,37\%. Kadar protein terendah biskuit terdapat pada perlakuan $\mathrm{C}$ (15 g alpukat : $15 \mathrm{~g}$ tepung ikan lele) yaitu sebesar $7,95 \%$.

\section{Saran}

Disarankan kepada masyarakat untuk memanfaatkan alpukat untuk menghilangkan bau amis ikan sehingga anak yang tidak suka ikan dapat mengonsumsi makanan yang mengandung ikan. Penelitian lanjutan dibutuhkan untuk mengamati masa simpan biskuit dengan alpukat dan tepung ikan lele sehingga baik untuk dikonsumsi oleh anak yang KEP.

\section{DAFTAR PUSTAKA}

Amirullah TC. 2008. Fortifikasi Tepung Ikan Tenggiri (Scomberomorus sp.) dan Tepung Ikan Swangi (Priacanthus tayenus) dalam Pembuatan Bubur Bayi Instan [skripsi]. Fakultas Perikanan dan Ilmu Kelautan. Institut Pertanian Bogor. Bogor.
[BPS] Badan Pusat Statistika. 2016. Sumatera Barat.

[BSN] Badan Standarisasi Nasional. 2011. Biskuit. SNI 2973-2011. Dewan Standarisasi Nasional. Jakarta.

Badan Standarisasi Nasional. 2005. SNI 01-7111.4-2005

Makanan

Pendamping Air Susu Ibu (MPASI). Bagian 4: Siap Santap http://websisni.bsn.go.id/index.ph p?sni_main/sni/detail_sni/7105 (Diakses, 24-11-2017).

Daftar komposisi Bahan Makanan (DKBM 2013).

[DEPKES] Departemen Kesehatan. 2013. Laporan Hasil Riset Kesehatan Dasar Nasional. Departemen Kesehatan. Jakarta.

Mardhatillah, 2008. Studi Pembuatan Crackers dengan Substitusi Tepung Ikan Gabus (Ophiocephalus striatus). Teknologi Pertanian Fakultas Pertanian Universitas Hasanuddin. Makassar.

Umar, Musdalifah. 2013. Studi Pembuatan Biskuit dengan Substitusi Tepung Ikan Gabus (Ophiocephalusstriatus)

[Skrispsi]. Jurusan Teknologi Pertanian Fakultas Pertanian Universitas Hasanuddin. Makassar 